\title{
A leitura nos cursos de licenciatura: análise e sistematização da produção acadêmica
}

\author{
Letícia Ferreira Corsino Oliveira*, Cláudia B. de C. Nascimento Ometto.
}

\section{Resumo}

Esta Iniciação Científica tem por objetivo identificar, por meio de uma revisão bibliográfica, quais/como tem sido as práticas de leitura nos diversos cursos de licenciatura. Tomamos como referências teóricas as perspectivas históricocultural do desenvolvimento humano de Vigotski (1989) e enunciativo-discursiva de Bakthin (2002). Para os quais a mediação do outro e a linguagem são constitutivas da condição humana, tornando os sujeitos capazes de tomar seus modos de ser, de agir e de dizer como objeto de pensamento e de reflexão. Compreendemos que o professor deve reconhecer o seu papel frente à promoção da leitura em sala de aula, pois sua postura frente a uma concepção de linguagem influencia em todo o processo de ensino e aprendizagem, principalmente nas interlocuções mediadas pelos textos. Por isso, decidimos investigar se as condições de formação de futuros professores favorece o trabalho com a linguagem, e consequentemente com a leitura, enquanto processo de interlocução.

Palavras-chave: Leitura, cursos de licenciatura, formação de professores.

\section{Introdução}

A presente Iniciação Científica parte de questionamentos sobre a formação de professores no que diz respeito às suas concepções de leitura na constituição dos sujeitos, enquanto futuros formadores de leitores. Analisa-se as produções acadêmicas que tomam como objeto de pesquisa as práticas de leitura de licenciandos dos diversos cursos, a fim de identificar como a temática vem sendo discutida neste ambiente. É, portanto, uma pesquisa de natureza bibliográfica.

No campo da linguagem temos nos voltado, mais especificamente, para os estudos sobre leitura entendendo-a como cotejamento de textos, uma vez que "toda palavra (todo signo) de um texto conduz para fora dos limites desse texto" (BAKHTIN, 1997, p. 404).

Consideramos também a importância não somente em se trabalhar a linguagem/leitura, mas de se ater para as concepções que se tem das mesmas. Para isto, nos pautamos nas concepções de linguagem elucidadas por Geraldi, que tem como referencial o próprio Bakhtin.

Entendemos a importância deste trabalho como um meio de identificar quais tem sido as condições de formação, com foco na leitura, de futuros professores que serão os responsáveis por inserir os alunos ao universo da leitura, na escola básica. Enfatizamos que esta não é uma tarefa exclusiva do professor de Língua Portuguesa.

\section{Resultados e Discussão}

Os eixos definidos que nortearam a pesquisa buscaram tratar sobre, 1. "Com que concepção de leitura os pesquisadores trabalham"; 2. "Como abordam os modos de apropriação, concepção e representação da leitura dos discentes"; 3. "Como abordam a representação social que o aluno tem de seu papel como futuro professor e formador de leitores"; 4. Como abordam a contribuição do curso de graduação, e/ou de uma disciplina do curso, para a formação leitora dos licenciandos"; 5. "Como abordam a relação entre leitura e aprendizagem no ensino superior"; 6. "Como abordam as relações entre a concepção de leitura sugerida pelos documentos oficiais dos cursos e a concepção dos professores e alunos dos mesmos"; e, por fim, 7. "Como abordam a relação entre leitura e escrita".

\section{Conclusões}

Embora a pesquisa ainda não esteja finalizada, os resultados parciais $(80 \%$ da pesquisa concluída) evidenciam que a leitura da literatura ainda aparece de forma escassa na formação de professores, além de que, fica evidente que considera-se uma tarefa exclusiva dos cursos de licenciatura em Pedagogia e em Letras. Além disso, por muitas vezes, nestes cursos, tem-se uma concepção de leitura da superfície textual, sem a busca de cotejamentos com outros textos ou conteúdos estudados, evidenciando uma leitura busca de informações em detrimento a leitura compreensão. A concepção de linguagem, portanto, caminha em direção oposta a uma concepção dialógica de leitura e linguagem como o lugar de constituição de sujeitos.

Agradecimentos

Agradeço à minha família, à minha orientadora e à Faculdade de Educação da Unicamp pela oportunidade de poder me inserir neste universo cheio de aprendizados e descobertas da pesquisa científica.

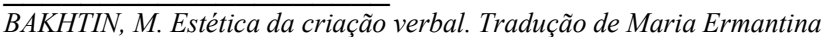
Galvão G. Pereira. 2. ed. São Paulo: Martins Fontes, 1997.,

GERALDI, J. W. Linguagem e ensino: exercícios de militância e divulgação. Campinas: Mercado das Letras: Associação de Leitura do Brasil (ALB), 1996. VYGOTSKY, L.S. A formação social da mente. São Paulo: Martins Fontes, 1989;
} 